CATALAN REVIEW

Catalan Review

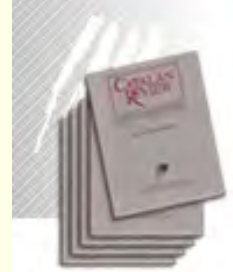

You are accessing the Digital Archive of the Catalan Review Journal.

By accessing and/or using this Digital Archive, you accept and agree to abide by the Terms and Conditions of Use available at http://www.nacs-

catalanstudies.org/catalan review.html

Catalan Review is the premier international scholarly journal devoted to all aspects of Catalan culture. By Catalan culture is understood all manifestations of intellectual and artistic life produced in the Catalan language or in the geographical areas where Catalan is spoken. Catalan Review has been in publication since 1986.
NORTH

AMERICAN

CATALAN

SOCIETY
Esteu accedint a l'Arxiu Digital del Catalan Review

A l' accedir i / o utilitzar aquest Arxiu Digital, vostè accepta i es compromet a complir els termes i condicions d'ús disponibles a http://www.nacs-

catalanstudies.org/catalan review.html

Catalan Review és la primera revista internacional dedicada a tots els aspectes de la cultura catalana. Per la cultura catalana s'entén totes les manifestacions de la vida intel lectual i artística produïda en llengua catalana o en les zones geogràfiques on es parla català. Catalan Review es publica des de 1986.

\title{
Constructing Catalanism: Motion Verbs, Demonstratives, and Locatives in the Spanish of Barcelona Robert E. Vann
}

Catalan Review, Vol. IX, number 2, (1995), p. 253-273 


\title{
CONSTRUCTING CATALANISM: MOTION VERBS, DEMONSTRATIVES, AND LOCATIVES IN THE SPANISH OF BARCELONA
}

\author{
ROBERT E. VANN
}

This his paper, based on fieldwork conducted in the summer of 1995 in Barcelona, analyzes some very polemic issues in Spanish and Catalan sociolinguistics today. What does it mean when a Catalan person speaks in Spanish? My analysis illuminates how the issues of ethnic identity and ideology are integrally related to language use by the native conception of linguistic resources in Barcelona. I argue that Catalan ethnicity and ideology are socially constructed, and since social interaction is mediated by language use, specific linguistic expressions constitute building blocks of Catalan ethnolinguistic and ideological identity, a.k.a. Catalanism. Woolard (1989:38) showed that language choice is an open expression of ethnicity in Catalonia and that speaking in Catalan indexes Catalan identity. The present paper illustrates that even when Catalan people do not speak Catalan, they can still communicate their ethnicity or sociocultural identity through the linguistic resources available to them in Spanish. Gal (1989:358) showed that it is often the case that subordinate groups subversively rework dominant linguistic forms, forging new forms and with them, new identities, out of the already symbolically weighted linguistic materials at hand. One resource available to Catalans when speaking Spanish involves innovations in the usage of Spanish motion verbs, demonstrative adjectives, and locative adverbs.

The paper is structured in four parts. The introductory section reviews Woolard's (1989) conception of language use and identity in Catalonia in terms of its potential drawbacks and attempts to expand on her analysis in the direction of my own research. The next two sections offer a theoretical account of the linguistic variables analyzed in the present study and a description of the methodological approach

${ }^{I}$ An earlier version of this paper, entitled "Ethnolinguistic Identity in Pragmatic Aspects of the Spanish Spoken in Barcelona," was presented at the VIII Colloguium of the North American Catalan Society on October 3, 1995. I thank those who made helpful comments at the conference, in particular Joan Solà, Milton Azevedo, Patricia Lunn, and Dorothy Noyes. All errors that remain are, of course, my own. I also acknowledge support from the Program for Cultural Cooperation between Spain's Ministry of Culture and United States' Universities, subvention \# I490. 
employed. Finally, the results of my study are presented and discussed in the form of claims regarding habitual choice of language, Catalanism, and innovative usage of motion verbs, demonstratives, and locatives in Spanish. My analysis is strictly qualitative, based on a logically developed argument and supported by quotations from my corpus. ${ }^{2}$

\section{IDENTITY, IDEOLOGY AND LANGUAGE USE IN CATALONIA}

One could say that more and more research relating to ethnic identity, ideology, and language use-such as Bourdieu (1991), Gal (1989), Irvine (I989), and Woolard (1985), among others-tries to acknowledge that social realities themselves are constructed, not given, and that, as such, the social world is a representation and a subjective perception of reality. The discourse on identity in this literature might address the question of Catalanist nationality or group identity as a matter of symbolic power, as in following quotation from Bourdieu (1991:221, italics in original):

Struggles over ethnic or regional identity...are a particular case of the different struggles over classifications, struggles over the monopoly of the power to make people see and believe, to get them to know and recognize, to impose the legitimate definition of the divisions of the social world and, thereby, to make and unmake groups.

In terms of the Bourdieu quotation, one struggle for power to define reality (and thereby ethnic expression) in Barcelona is currently wrapped up tightly in the language question. According to Woolard (1989:38-39), daily life in modern-day Barcelona constantly involves the creation and expression of identities (both as Catalan and as Castilian), most often through language use: "As a Catalan is one whose native and habitual language is Catalan, so a Castilian is a person whose

${ }^{2}$ Concerning issues of representation, I try to contextualize all quotations by providing information regarding the speakers involved, the group within which they have been analyzed, the kind of interview from which the quotation has been taken, the date of the interview, and the page and line number of the quotation as referenced in my transcriptions. The context of discussion into which all quotations fall is informal conversation regarding the definition of what it means to be Catalan, the usage of Spanish and/or certain deictics in Spanish, and perceived meanings of such usage. The English translations are my own understandings of the content of the dialogs. Although I have tried to remain true to original syntax and word choice where possible, I realize that my translations may not always accurately represent a give speaker's actual intent or personal meaning. 
native and habitual language is Castilian." She cited other criteria used in popular constructions of Catalan identity, such as birthplace, descent, and sentiment; however, she maintained that "these three different criteria of identity, though accepted in certain contexts, are all completely eclipsed by a single predominant shibboleth of group membership: language." This concept of what I will call "ethnicity through habitual choice of language" is not without complications.

The general problem with Woolard's characterization lies in its simplification of complex constructions. Constructs such as ethnicity and identity are often difficult to define with precision, and although at times these constructs may appear to go hand-in-hand with habitual choice of language, one must be careful not to reduce them to nothing more than language choice. Milroy (1987b:103) offered the following basic interpretation of ethnicity: "an individual's sense of belonging to a distinctive group whose members share a common history and culture." She explained that, although ethnicity is not synonymous with racial or regional origin, all of these constructions contribute to a general sense of distinctiveness with which a certain sense of linguistic distinctiveness is often associated.

When ethnic groups exist within larger states, the question of autonomous politics can arise, creating an ideology that can then also become associated with distinct cultural groups. Eagleton (1994:II) has claimed that ideology denotes "the points at which our cultural practices are interwoven with political power." Geertz (1994:287) has gone so far as to claim that "the function of ideology is to make an autonomous politics possible by providing the authoritative concepts that render it meaningful, the suasive images by means of which it can be sensibly grasped." Thus, one finds that ethnic and ideological differences are often magnified by corresponding differences in political, cultural, or even religious agendas, as one can observe in current situations in Northern Ireland, Israel, and the former Yugoslavia. When this is the case, the heightened awareness of the differences is frequently marked by efforts to maintain and even create linguistic distinctiveness, as seen in perceptions of spoken Hindi and Urdu (or, for that matter, spoken Catalan and Valencian) as completely different languages. Labov (1972:281) has shown, however, that ethnicity is not always marked by continued linguistic distinctiveness. For this reason, one must remember that ethnicity and ideology are culturally constructed categories, not given or objective

"In contrast to Woolard's differing use of terminology, I use to words "Spanish," "Castilian," and "Catalan Spanish" to refer to a generalized abstraction of the language, the variety of that language spoken by (non-Catalan) Spaniards, and the variety of that language spoken by many Catalans, respectively. 
realities, and that, above all, ethnic identity and ideology represent much more than just language choice. Thus, reductionism is the general, theoretical difficulty with Woolard's model. In addition to this theoretical aspect, there are also two other factors, particular to the Catalan situation, that pose more specific difficulties for Woolard's concept of ethnicity through habitual choice of language.

One specific difficulty is posed by "norms" for language use. The Catalan language is both a marker and a reinforcer of ingroup solidarity. Woolard (1989:69) held that when only Catalans are present, speaking Spanish is rare; however, when a Castilian-only speaker is suspected or known to be present within a group of Catalans, many Catalans will switch to Spanish, at least when addressing that speaker. This phenomenon is what Woolard $(1989 ; 69)$ called the "accommodation norm," which contrasts with what she denominated (1989:77) the "bilingual norm," whereby the speaker's own identity will determine his or her choice of language during intergroup interaction, regardless of the (perceived) identities of the interlocutors. Within this model, by definition, the bilingual norm affirms language choice as a resource of ethnolinguistic assertion. Catalans who proudly speak Catalan all the time, irrespective of the ethnolinguistic identities of their interlocutors, openly communicate their ethnic identity. Conversely, the accommodation norm obscures language choice as a resource of ethnolinguistic assertion. Those who habitually express their Catalan identity by speaking Catalan with Catalan interlocutors, but who follow the accommodation norm whereby they habitually switch to Spanish for the sake of monolingual Spanishspeaking interlocutors, seem not to fit neatly into Woolard's model. For individuals in such a situation, habits of language choice do not seem to be expressing ethnicity. Thus, it would not be surprising to discover that when speaking Spanish and wishing to communicate their cultural identity, such Catalans find other resources to do so.

Another difficulty posed by the ethnicity through habitual choice of language argument relates to proficiency and conditioned use patterns. Life is not likely to be as simple as choosing to express oneself in Catalan or Castilian for the purpose of communicating identity, because not all Catalans can express themselves very well in written Catalan, nor can all do so in everyday spoken discourse. According to Fishman (1991:313), Catalan people are frequently most literate in Spanish. In fact, Noyes (1992:40) went so far as to document that many Catalans educated in the Franco years are functionally illiterate in their own language. Further, these same individuals will often turn to Spanish in public and/or official domains. In these cases, the habitual choice of Spanish need not represent an ethnolinguistic 
statement of Spanish identity; chances are it has more to do with language proficiency and conditioned use. What is key and what will be developed shortly, however, is that even speaking Spanish habitually may be taken as a statement of Catalanism, depending on how that Spanish is spoken, i.e., whether it is realized with a Castilian or Catalan accent or other indexing quality.

Woolard (1989:70) noted that during a conversation, "If a Catalan accent is detected in an interlocutor's Castilian, this may induce a Catalan speaker to ask for confirmation of language choice...Ets català? (Are you Catalan?)" Woolard's use of the term "accent," presumably referring to pronunciation, highlights the importance of linguistic resources other than language choice in constructing Catalan identities and ideologies. Yet accent as such a resource is also problematic, because it is widely known that most residents of Barcelona, Catalan or not, have a recognizably different pronunciation of Castilian than do monolingual Castilian speakers in the rest of Spain. As Seco has commented (1989:309, my translation), "the average Castilian speaker is accustomed to easily detecting the Catalan substrate that is more or less present in the phonetics of those from the Catalan lands." Furthermore, within Barcelona itself, since many people have such an accent regardless of their ethnic identity, conclusions regarding ethnicity based solely on pronunciation are somewhat suspect. There are, however, other potential resources to assert Catalan identity or ideology while speaking Spanish. One possible resource could be a nonphonological, yet linguistic, resource within the Spanish language itself. This possibility is supported by Gal (1989:357), who claimed that "not only code-switching and language choice, but grammatical processes as well can be interpreted as symbolic expressions of identity." In my research, I have found just such a resource.

\section{LINGUISTIC VARIABLES}

A deictic word or phrase is one that specifies identity or spatial or temporal location from the perspective of one or more of the participants in a communicative act; e.g., in English, words like bere, there, come, go, bring, take, this, that, yonder, etc. Such positional words take on different referents depending on the identity and location of the speakers and the time when the conversation takes place. Because pragmatics is the branch of linguistics that takes building blocks such as participant identity and location into account, the precise combination of these building blocks that determines the use of a given deictic can be called the "pragmatic scope" of the deictic. 
Crosslinguistically, the pragmatic scope of deixis varies. In Catalan, deictic verbs of motion, demonstratives, and locatives are cognate in form but different in pragmatic scope from the corresponding words in Castilian. Catalan includes the location of the addressee in the deictic center of these words whereas Castilian is entirely speakercentered. The deictics involved are given in Table 1 . The verbs are given as infinitives and the adjectives are given in their masculine singular forms.

\section{TABle 1: Pragmatic Scope of Certain Deictics in Catalan and Castilian$$
\text { ([s] = location of speaker, }[\mathrm{a}]=\text { location of addressee })
$$

\begin{tabular}{|c|c|c|}
\hline Gloss & Catalan: deictic and scope & Castilian: deictic and scope \\
\hline come & venir: motion towards $[\mathrm{s}]$ or $[\mathrm{a}]$ & venir motion only towards [s] \\
\hline go & anar: motion not towards [s] or [a] & ir: motion only away from [s] \\
\hline \multirow[t]{2}{*}{ bring } & portar: motion $[+o b j]$ towards & $\begin{array}{l}\text { traer: motion [+obj] only } \\
\text { towards [s] }\end{array}$ \\
\hline & & {$[s / a /$ other $]$} \\
\hline take & “ & $\begin{array}{l}\text { Llevar: motion [+obj] only away } \\
\text { from [s] }\end{array}$ \\
\hline this & aquest: object near [s] or [a] & este: object near [s] \\
\hline that & $" \alpha$ & ese: object not too far from $[\mathrm{s}]$ \\
\hline yonder (adj.) & aquell: object not near [s] or [a] & aquel: object very far from [s] \\
\hline here & aquí: object near [s] or [a] & aqui: object near $[\mathrm{s}]$ \\
\hline there & & abí: object not too far from [s] \\
\hline yonder (adv.) & allà: object not near [s] or [a] & alli: object very far from [s] \\
\hline
\end{tabular}

Catalans who learn to speak Spanish must internalize a speakercentered point of view when using these positional terms. Several factors work against this internalization, such as the traditional inclusion of the addressee in the pragmatic scope of the Catalan deictics (cf. Table 1), the similarity in form of the motion 
verbs/demonstratives/locatives in Catalan and Spanish, and the prestigious nature of Catalan in Catalonia. Thus, it is not surprising that, at times, Catalans who speak Spanish extend the scope of these Spanish deictics to include the addressee. Many Catalan-Spanish bilinguals do in fact use these Spanish deictics according to the pragmatic scope of the corresponding Catalan deictics. I will refer to the result of this transfer as an element of "Catalan Spanish." This innovation of an extended scope to include the addressee can obtain for the Spanish verb venir "come" (formally similar to venir in Catalan), the Spanish verb traer "bring" (no cognate in Catalan), the Spanish demonstrative este "this" (formally similar to aquest in Catalan), and the Spanish locative aquí "here" (formally identical to aqui in Catalan). In Catalan Spanish, the extended pragmatic scope of the deictics can obviate the use of the second term in the case of the paired motion verbs and the middle term in the case of the tripartite demonstratives and locatives, as shown below, in Table 2:

\section{TABle 2: Extended Pragmatic Scope of Certain Deictics in Catalan Spanish}

\begin{tabular}{|c|c|c|c|c|c|c|c|}
\hline English & $\begin{array}{l}\text { Catalan } \\
\text { Spanish }\end{array}$ & English & $\begin{array}{l}\text { Catalan } \\
\text { Spanish }\end{array}$ & English & $\begin{array}{l}\text { Catalan } \\
\text { Spanish }\end{array}$ & English & $\begin{array}{l}\text { Catalan } \\
\text { Spanish }\end{array}$ \\
\hline $\begin{array}{l}\text { come } \\
\text { go }\end{array}$ & venir & $\begin{array}{l}\text { bring } \\
\text { take }\end{array}$ & traer & $\begin{array}{l}\text { this } \\
\text { that } \\
\text { yonder } \\
\text { (adj.) }\end{array}$ & $\begin{array}{l}\text { este } \\
\text { aquel }\end{array}$ & $\begin{array}{l}\text { here } \\
\text { there } \\
\text { yonder } \\
\text { (adverb) }\end{array}$ & aquí \\
\hline
\end{tabular}

To illustrate the different treatment of the deictics under consideration, it might be helpful to consider some specific examples. Compare the motion verbs used to respond to a doorbell in monolingual Castilian Spanish (Ia), Catalan (Ib), and Catalan Spanish (Ic):
Ia) ¡Ya voy/("vengo)! I'm going/("coming)!
ib) Ja vincl("vaig)!
I'm coming/("going)!

[monolingual Castilian ]

\{Catalan\} 


\section{Ic) iYa vengo! \\ I'm coming!}

\{Catalan Spanish\}

Next, compare the motion [+obj] verbs used in a telephone conversation between friends, each of whom is at home. One party needs to borrow a few books from the other, as expressed in monolingual Castilian Spanish (2a), Catalan (2b), and Catalan Spanish (2c):

2a) Ya te los llevo/("traigo) a tu casa. I'll take/(*bring) them to your house.

2b) Ja t'els porto a casa teva.

I'll bring them to your house.

2c) Ya te los traigo a tu casa. I'll bring them to your house.

\{monolingual Castilian\}

\{Catalan\}

\{Catalan Spanish\}

Now compare the demonstratives used to contrast two objects-one that is clearly near the speaker but far from the hearer versus one that is clearly near the hearer but far from the speaker-in monolingual Castilian Spanish (3a), Catalan (3b), and Catalan Spanish (3c). The speaker and the hearer are across the street from one another:

3a) Me gusta este delante mío,

no esel("este) detrás tuyo.

I like this one in front of me,

[monolingual Castilian\} not that/ ("this) one behind you.

3b) M'agrada aquest davant meu,

no pas aquest darrera teu.

I like this one in front of me,

\{Catalan\}

not this one behind you.

3c) Me gusta este delante mío,

no este detrás tuyo.

I like this one in front of me,

\{Catalan Spanish) not this one behind you.

Finally, compare the locatives used in a telephone conversation between two people in different countries, in monolingual Castilian Spanish (4a), Catalan (4b), and Catalan Spanish (4c):

4a) ¿Sabes que mi madre está abí/("*aquí) en tu país? 


\section{Did you know my mother is there/("here) in your country? \\ \{monolingual Castilian\}}

4b) Saps que la meva mare és aqui/("allà) al teu pays? [Catalan]

Did you know my mother is bere/("there) in your country?

4c) ¿Sabes que mi madre está aqui en tu país? Did you know my mother is here in your country?

\{Catalan Spanish\}

\section{THE METHODOLOGY USED IN THE STUDY}

Previous studies by the author (Vann 1993, 1996) have suggested that the innovative usage of these deictics in the Spanish of Catalans is closely related to issues of ethnic identity and ideology. For the purposes of the present study, in order to examine these relationships, two personal networks were examined. Building on the work of Milroy (1987a), Gal (1979), and Edwards (1986), I utilized the concept of social network to reflect the degree to which speakers (a) have dense, multiplex ties within the Catalan community in Barcelona and (b) share the norms, values, beliefs, and sociocultural or political attitudes and relationships that are used to construct their ethnocultural and ideological identification. As in Milroy's (1987a) Belfast study, personal networks were examined. As in Gal's (1979, 1989) studies, networks were used to distinguish culturally relevant categories in a bilingual situation. The culturally relevant factors examined through the networks were ethnic identity and ideology, following Edwards' (1986) lead.

To discover the relationship between ethnicity, ideology, and language use in the community under consideration, I assumed the roles of both friend and investigator to enter successfully into the personal networks of two fieldworkers, each of whom had been chosen as ego in her respective network. From the start, fieldworkers were sought whose networks differed markedly from each other in habits of language use.

The personal networks were identified following a method that, independently, both Cubitt (1973) and Gal (1979) have shown to be successful in language and social network studies; the fieldworkers, as central individuals of their respective networks, were asked to keep a one-week log of the people they encountered.

From these logs a master list was made for each network. Everyone on the two master lists was contacted to obtain permission to record some of their interactions. It was explained that to 
participate, informants would have to consent to being recorded in Spanish. ${ }^{4}$ Before any interviewing was done, the investigator became a peripheral member of each network, and informants got used to the investigator's presence as a participant in each community. Because of the fieldworkers' general language use patterns, the final sample consisted of one network of 26 people in which members habitually speak Spanish (referenced in quotations to follow as S) and another of 32 people in which members habitually speak Catalan (referenced in quotations as C).

Once the investigator had become associated with the networks in question, the data collection formally began. The individual interview format was used and group interactions among network members were observed to attain extensive qualitative data. Nearly 80 hours of conversation were recorded. The interviews were conducted before the group sessions, so that in the group sessions, informants could later be asked to comment metalinguistically on the linguistic variables tested in the interviews. This ordering may have made the linguistic nature of the study obvious from the start; however, it also facilitated the investigator's access to information that individual informants might not have revealed had the group sessions come first and had the informants had time to dwell on the nature of the linguistic variables.

The interviews were carried out by the investigator alone, in light of specific research on "insider" versus "outsider" advantages in this community:

The general principle that informants tend to avoid expressing opinions or using linguistic forms that might displease or offend the [Castilian or Catalan] interviewer (or third parties present) supports the concept of an "outsider advantage." The foreign fieldworker, while he or she may engender other biases, likes, and dislikes, does not enter directly into the Castilian-Catalan linguistic and ethnic conflict. Just like Katz's "outsider with the proper prestige," the survey researcher who speaks with a foreign accent in both Castilian and Catalan may elicit responses that native Castilian or Catalan ears may never hear. (O’Donnell $1989: 128$, italics in original)

Thus, in a nation where third-party effects and bias introduced by interviewer demographics can be very strong, the question of

4 The consent forms issued, as well as the methodology of the entire study, received prior approval (on $05 / 15 / 95$ ) from the University of Texas Institutional Review Board for Protection of Human Subjects in Research Investigations, for compliance with DHHS/PHS-NRA, Public Law 93-348, as enunciated through Code of Federal Regulations 45 CFR 46, Protection of Human Subjects (revised as of August 19, 1991), and for compliance with the University's Institutional Multiple Project Assurance, Number M-1wo-or. 
matching or varying interviewer and informant social variables was averted in the present study due to the fact that the investigator (an outsider) carried out the interviews personally. All interviews were conducted in Spanish.

In the interviews, informants were prompted first orally and then visually to imagine certain situations and provide the deictics they would use to describe the situations. Next, the informants were presented with a written dialog highlighting the target deictics and asked to rate each deictic in its context on a scale of grammaticality. Informants were then asked to comment on the cultural significance, if any, that the use of these words in Castilian held for them. Finally, information was gathered on language background and sociocultural views. Set questionnaires were administered to gauge relative exposure to Spanish versus Catalan, network integration, ethnic identity, and ideology. For the purpose of provoking discourse on identity and ideology, informants were asked a number of specific questions, such as whether they believed that Catalonia is a country or just a region in Spain, whether they had a positive or negative opinion of King Juan Carlos, etc. Furthermore, informants were asked whether their own views on ideology, culture, language use, and politics tended to resonate more with those of the Catalan or the Spanish society at large. The questionnaire for identity and ideology has been reproduced in the Appendix.

Several days after informants were interviewed individually, the fieldworkers invited them over their houses for coffee or drinks in groups of three, either in the afternoon or in the evening. All the group sessions were video- and audiorecorded for about one hour. During these sessions, the investigator was present mostly as an observer only, while the fieldworker introduced and tried to maintain specific topics, or modules, of conversation.

Each group session had three modules, with conversational management from the fieldworker and minimal questioning from the investigator. The first module concerned the informants' own network relations. Informants would speak about how, when, and where they met, etc. This would naturally lead into conversations about the current relationships between the informants and their friends in the network. The second module of the interactions concerned informants' attitudes towards the expression of identity through language in Barcelona. Informants were asked about the impressions and perceptions people have about Catalans and Castilians when they speak Castilian. This conversation would lead into the last module, in which informants would be asked to comment metalinguistically on the tasks they performed in the previous individual interviews. They 
would be informed that, during the personal interviews, not everybody had agreed on their grammatical intuitions in Spanish. Informants would then be asked to discuss the matter in light of its social significance, if any. Most people seemed comfortable speaking about their own grammatical intuitions and those of others; in general, the informants were very interested in and willing to discuss such linguistic matters openly.

\section{RESULTS}

The informants' metalinguistic reactions, in both the individual interviews and in the group sessions, offered important insight into how Catalans and Spaniards themselves might actually view the usage of the deictics. Many links between deictic use and ethnolinguistic identity were revealed. Several qualitative conclusions can be drawn from data recorded during the individual and group sessions.

Regarding the construction of ethnic identity, ideology, and the social significance of the pragmatic transfer associated with the deictics, the following three claims are supported for the two networks:

1) The division in Catalan versus Spanish identities and ideologies is not based on habitual choice of language.

2) There is a different working definition of what it means to be Catalan for each group.

3) Transfer is not on purpose, but it is certainly "not minded" if others notice the innovative usage (of motion verbs, demonstratives, and locatives) and index the speaker as a Catalan.

I) It would seem that the difficulty in explaining how Catalans and Spaniards index their identities lies in the analyst's definition of each of these groups. The problematic nature of any analysis that includes ethnicity lies in its subjectivity. While some of my informants agreed with Woolard's shibboleth of habitual language, most cited other criteria as the most important in describing Catalan identity and ideology. The two quotations below show that, for individuals in each group, speaking Catalan is not the primary criterion in constructing Catalan identity or ideology:

$\mathrm{X}=\mathrm{S} \mathrm{I}-\mathrm{I}$, habitually Spanish-speaking group, individual interview; page ro, lines 44-46; June 7, 1995:

$\mathrm{X}$ : Aquí hay mucha gente.. que hablamos castellano y no pasa nada. $\mathrm{O}$ sea, no.. 
no somos.. o sea, yo soy y me siento catalana y.. yo voy a favor de la política de Cataluña, pero si no hablo catalán, no pasa nada. $O$ sea no lo consideramos tan importante, 5

$\mathrm{X}=\mathrm{C}_{\mathrm{I}}-8, \mathrm{R}=$ investigator, habitually Catalan-speaking group, individual interview; page 4, lines $\mathrm{I}_{3}-\mathrm{I7}$; June I4, 1995:

$\mathrm{R}$ : Y un catalán, para ser catalán ¿̨hay que hablar catalán?

$X:$ No.

$\mathrm{R}: \mathrm{O}$ sea, ¿puede puede que existan catalanes que no sepan catalán?

$\mathrm{X}$ : Sí, y quieran igual a a su tierra, es decir, porque hables en catalán o castellano, no,., no tiene nada que ver.. una cosa con la otra. ${ }^{6}$

2) An outgrowth of claim number one is that while many individuals in both groups agreed that habitual language was not the most important criterion in group membership, their ideological reasoning was different. In general, in the habitually Spanish-speaking network, attributes such as being born in Catalonia were deemed most important, whereas in the habitually Catalan-speaking network, "feeling" Catalan was more important. Many in the habitually Spanish-speaking group do self-identify as Catalans, based on birthright. However, based on distinct criteria of group membership, those in the habitually Catalan-speaking group conceivably might not consider these people to be Catalans. The quotation below stresses birthright as most important to Catalan identity:

$\mathrm{X}=\mathrm{S}_{\mathrm{I}}-12, \mathrm{R}=$ investigator, habitually $\mathrm{Spanish}$-speaking group, individual interview; page 2, lines 3-11; June 27, 1995:

R: Y-

$\mathrm{X}$ : Bue-, es que no eres catalán. Puedes hablar perfectamente catalán y sentirte supercatalán, más que yo, pero luego-

R: Pero no.. no lo sería.

${ }^{5} \mathrm{Cf}$. Note 2. An approximate translation of the quotation in the text follows below: $\mathrm{X}$ : Here there are a lot of people... we speak Spanish and it's no big deal. I mean, we're not, I mean, I am and I feel Catalan and I go in favor of the politics of Catalonia, but if don't speak Catalan, it's no big deal. We just don't consider it so important.

${ }^{6} \mathrm{Cf}$. Note 2. An approximate translation of the quotation in the text follows below:

$\mathrm{R}$ : And a Catalan, in order to be Catalan, is it necessary to speak Catalan?

$\mathrm{X}:$ No.

$\mathrm{R}$ : So, could there be Catalans who don't know Catalan?

$\mathrm{X}:$ Yes, and who love their land just the same; that is, because you speak in Catalan or Spanish, one thing doesn't... one thing doesn't have anything to do with the other. 
$\mathrm{X}$ : No serias para mí, porque eres si naces. Es como si me de- te tînes de rubio, pues.. yo, voy teñida de rubio, pero soy morena. Soy morena porque he nacido asi. Si voy teñida de rubio, pues me queda muy bien, y mejor rubia que morena, pero yo.. soy morena.

$\mathrm{R}$ : Y uno que nace aquí pero que no comparta.. ninguna ideología catalana ¿todavía es catalán?

$\mathrm{X}$ : ¡Claro que es catalán!?

The following quotation, from the habitually Catalan-speaking group, contrasts with the previous quotation. It stresses "feeling" Catalan as most important to Catalan identity:

$\mathrm{X}=\mathrm{CI}_{\mathrm{I}-\mathrm{I} 4}, \mathrm{R}=$ investigator, habitually Catalan-speaking group, individual interview; page $\mathrm{I}_{2}$ lines 10- $\mathrm{I}$; June $2 \mathrm{I}$, 1995 :

$\mathrm{R}$ : O sea, uno no puede ser catalán si no.. ¿qué?

X: Si no se siente catalán.

$\mathrm{R}$ : O sea, lo.. lo primero es sentirse catalán.

X: Sí. Más que hablarlo. ${ }^{8}$

The next quotation, also from the habitually Catalan-speaking group, alludes to how, in that group, some might not accept the birthright criterion of the other group as valid. To qualify as a Catalan for the informant quoted below $\left(\mathrm{CI}_{-}-7\right)$, and for many in group $\mathrm{C}$, people must be exposed to Catalan traditions and take them to heart, no matter where they are born:

$\mathrm{X}=\mathrm{C}_{\mathrm{I}-7}, \mathrm{R}=$ investigator, habitually Catalan-speaking group, individual interview; page 2, lines 52-55; June 14, 1995:

7 Cf. Note 2. An approximate translation of the quotation in the text follows below:

R: And-

X: Well, you're just not Catalan. You could speak Catalan perfectly and feel superCatalan, more than me, but then-

R: But I wouldn't be.

X: You wouldn't be for me, because you are if you're born that way, It's like I- if you dye your hair blond, well... I go around with my hair dyed blond, but I'm a brunette. I'm brunette because I was born that way. If $I$ go around with my hair dyed blond, well, ir looks good one me, and better blond than brunette, but $I_{\ldots .}$ am a brunette,

$R$ : And a person who is born here but who doesn't share....ny Catalan ideology, is such a person still Catalan?

$\mathrm{X}$ : Of course the person is Catalan!

${ }^{8} \mathrm{Cf}$. Note 2 . An approximate translation of the quotation in the text follows below:

R: So, a person can not be Catalan if the person does not... what?

$X$ : If the person does not feel Catalan.

$\mathrm{R}$ : So, the most important thing is feeling Catalan.

$\mathrm{X}$ : Yes. More than speaking it. 
$\mathrm{X}$ : $\mathrm{O}$ sea, a yer, un catalán nacido aquí, y que reniegue.. y que, no sé, y que, que no sienta nada por Cataluña ni nada, pues, para mí vale menos... pero para mí vale menos que otra persona que a lo mejor.. no ha nacido aqui, pero, pero por lo que sea, pues, pues siente Cataluña y.. y.. y no sé, y siente sus tradiciones... ${ }^{9}$

Like the quotation above, there are many others, originating from speakers in both groups. At this point it might be helpful to stress that the group classifications referenced in this paper have been imposed from outside as a methodological convention for the purpose of analysis. We have already seen that habitual choice of language is not an ethnically or ideologically divisive characteristic for the groups I have labeled $\mathrm{S}$ and $\mathrm{C}$, and habitual language was the criterion originally used to select fieldworkers and their networks. Therefore, the groups should not be construed as ethnically or ideologically homogeneous; conclusions regarding the groups are not meant to hold across the board for all individuals within a given group. If one wanted to reclassify the informants into ethnically or ideologically homogeneous groups, then given individuals that have thus far been analyzed in this paper as members of group $S$ might more naturally fall into group $\mathrm{C}$ based on their beliefs and language use, and vice-versa. ${ }^{10}$ Of course, such groups would cease to represent actual social networks. Because the present analysis is concerned with the actual social networks observed, which are not completely homogeneous in ethnic and ideological identification, the conclusions reached here regarding quotations from members of either group can be taken as valid, to a certain degree, for other individuals in the sample at large.

3) The last qualitative conclusion that I have drawn is that pragmatic transfer in deixis in the Spanish spoken by members of these networks is not on purpose, but it is certainly "not minded" if others notice it and index the speaker as a Catalan. Informants admittedly do not mind that others can tell that they are Catalan based on their innovative usage of the deictics examined. Although some know their use of the deictics is not "correct," and they know the "correct" forms,

'Cf. Note 2. An approximate translation of the quotation in the text follows below:

X: I mean, let's see, a Catalan born here, but who turns his back... and who, I don't know, and who, who doesn't feel anything for Catalonia or anything else, well, for me such a person is worth less... but for me such a person is worth less than some other person who maybe... wasn't born here, but, but who, for whatever reason, well, lives (feels) Catalonia and,... and... I don't know, and lives (feels) its traditions.

to Such an analysis could be carried out quantitatively for each individual as a measure of the individual's integration into a constructed ethnic or ideological group; however, this type of analysis is beyond the interest of the present qualitative analysis. 
they choose to do it their way anyway. The quotations below suggest both a pragmatic convention of structural continuity (in terms of discourse coherence) and an element of Catalan solidarity attached to the pragmatic transfer in deixis. The first quotation below alludes to the urge on the part of some informants to follow some sort of pragmatic convention of structural continuity.

$\mathrm{X}=\mathrm{S} \mathrm{I}-\mathrm{I} 2, \mathrm{R}=$ investigator, habitually Spanish-speaking group, individual interview; page I, lines 4-10; June 27, 1995:

$\mathrm{X}$ : ¿Sabes que pasa?, que.. es difícil porque a veces según con la persona que estés hablando, hablas de una manera o de otra. Si.. si un amigo te dice: "¿Me traes los apuntes?," "Sí, ahora te los traigo." Pero, si te dice: "¿Me vienes a buscar?," "Sí, ahora voy." Mhm no sé. ¿Sabes?

R: Si.

$\mathrm{X}$ : Si estás hablando con un interlocutor que utiliza ese.. ese código, como dirías tú posiblemente, pues, muchas veces lo.. lo sigues tú también.

When speaking Spanish, some bilinguals also use the pragmatic transfer in deixis to orient themselves towards the ethnolinguistically Catalan speech community and its identity or ideology. The next quotation alludes to the social significance of pragmatic transfer in deixis and shows a positive evaluation of the transfer if it is used to communicate Catalan identity:

$\mathrm{X}=\mathrm{C}_{\mathrm{I}}-\mathrm{L} 4, \mathrm{R}=$ investigator, habitually Catalan-speaking group, individual interview; page 7 , lines 45 -50; June 2I, r995:

R: Tú crees que.. que si alguien te habla castellano, y y dice.. y mezcla un poco el ir y venir o el el el aquí y abí y todo esto, stú te crees que esto para ti te te indica algo? cuando alguien te diga-

$\mathrm{X}$ : Lo primero que me sugiere es que está hablando en castellano forzadamente; es decir que es catalana. Y després [sic] si yo ya lo noto en el acento que no es caste-que no es catalana, me sugiere que, queda un poco así, below:

"Cf. Note 2. An approximate translation of the quotation in the text follows

X: You know what happens? It's hard because at times, depending on the person you're speaking with, you speak one way or another. If... if a friend says to you: "Will you bring me the notes?," "Yea, l'll bring them to you now." But, if the friend says: "Will you come pick me up?," "Yea, I'm going now." I don't know. You know?

R: Uh huh.

$\mathrm{X}$ : If you're speaking with an interlocutor that uses that... that code, as you might possibly say, well, often times you follow it as well. 
pero me sugiero que.. me sugiere que no tiene un nivel, eh.. un nivel intelectual muy alto, o sea que no ha estudiado suficientemente... ${ }^{12}$

Thompson (1991:39) reminds us in his introduction to Bourdieu's (199I) book that "each recipient helps to produce the message which he perceives and appreciates by bringing to it everything that makes up his singular and collective experience." In other words, the Catalanist ethnic or ideological message, intended or not, can be present in the usage of the deictics for those able and willing to hear it. This reasoning supports the idea that identity and ideology are related to exposure to Catalan ways of speaking, in this case, exposure specifically to a certain way that Catalan people sometimes use deictics in Spanish. Recognizing and appreciating a cultural message associated with a particular use of language implies prior exposure to the linguistic expression used and prior exposure to and internalization of the cultural message conveyed, i.e., a certain degree of communicative competence. ${ }^{13}$ The cultural message and its ideological interpretation are discussed in the quotation below, in which the fieldworker for group $\mathrm{S}$, two informants, and I are talking about why Catalan people sometimes avoid the so-called "middle" positional terms of ahi and ese in Spanish:

$\mathrm{X}=\mathrm{S}_{\mathrm{I}-\mathrm{I}}, \mathrm{Y}=\mathrm{S}_{\mathrm{I}-26}, \mathrm{FW}=$ fieldworker, $\mathrm{R}=$ investigator, habitually Spanishspeaking group, group session $\mathrm{S}_{2}-6$; page 12 , lines $\mathrm{I}-23$; July 22, 1995:

FW: En español tienes más palabras. Tienes este, ese, aquel. En catalán es aquest y aquell. No no, no es que hay una norma, es que-

X: ¿No.. no crees que se podría evitar un poco más? ¿̨est- est- o sea, estos rasgos lingüísticos?

FW: ¿Cómo?

$\mathrm{X}$ : De alguna manera, no se evitan, es una hipótesis, ¿eh? No se evita porque, eh, quizás inconscientemente de esta manera, eh, fuera, llevamos por delante, para que los demás se den cuenta-

${ }^{n} \mathrm{Cf}$. Note 2. An approximate translation of the quotation in the text follows below:

R: Do you think that... that if someone speaks to you in Spanish, and says... and mixes go and come a little bit, or bere anf there and all that, do you think that for you this means any thing? when someone says to you-

$X$ : The first thing that it suggests to me is that person is speaking in forced Spanish; that is to say that the person is Catalan. And then if I notice in the person's accent that he or she is not Catalan, it suggests to me that, well it looks a little bad, but it suggests to me that the person is not very smart, or hasn't studied enough.

${ }^{13}$ For this reason, the precise relationship between cultural/linguistic exposure and the recognition/use of these expressions is in area worthy of future research. Relative exposure to Catalan and Spanish in language acquisition indeed appears to be a key factor in establishing the relationship between ideology and deictic use (Vann 1996, Vann In preparation). 
FW: Esto, esto, es una ??.. para él [gestured reference to R].

$\mathrm{X}$ :... de que somos catalanes?

Y: Esto, para él [reference to R] es muy interesante, me parece.

FW: Sí. Sí sí...

$\mathrm{X}$ : Es es una hipótesis. El otro día después de haber hablädo contigo [reference to $R$ ] en la entrevista, me vino a la cabeza.

$\mathrm{R}: \mathrm{Y}$ ¿cuál es la hípótesis?

$\mathrm{X}: \mathrm{M}$, pues, lo que acabo de decir, pues ahorita, pues esto. Eh... que que sea un mecanismo inconsciente de no hablarlo... tan bien como podría- como podríamos hablarlo. Y más te gustará si lo notan... si.. si eres catalanista, evidentemente, ¿no?

Y: Hombre claro.

... [line deleted for anonymity]

$\mathrm{X}$ : Pues, que lo noten, que lo noten.

$\mathrm{R}:$ Que lo noten.

Y: Que lo noten.

$\mathrm{X} / \mathrm{Y}: \mathrm{Si}^{1+}$

To conclude, it would seem that there is a division based on identity and/or ideology within the bilingual community studied. This below:

${ }^{14}$ Cf. Note 2. An approximate translation of the quotation in the text follows

FW: In Spanish you have more words. You have this, that, yonder. In Catalan it is this and yonder. No no, there just isn't any rule-

$\mathrm{X}$ : Don't you think that people could avoid them a little more, these linguistic tokens?

FW: How's that?

X: In some way, don't you avoid them, it's only a hypothesis, okay? Don't people avoid them because, uh, maybe unconsciously in this way, uh, on the outside, we wear it on our sleeves, so others will realize-

FW: That is... for him [gestured reference to R].

$\mathrm{X}$ :...That we're Catalans?

Y: It would seem to me that, for him [reference to R], that is very interesting,

FW: Exactly.

$\mathrm{X}$ : It is a hypothesis. The other day after having spoken with you [reference to R] in the interview, it came to me.

$\mathrm{R}$ : And what is the hypothesis?

$\mathrm{X}$ : Uhh, well, what Y just said, right now. Uhh... that it may be an unconscious mechanism of not speaking it... as well as I could - as we could. And it will probably please you more that others notice it... if... if you are a Catalanist, evidently, right?

Y: Of course.

... [line deleted for anonymity]

$\mathrm{X}$ : Well, let them notice, let them notice!

$\mathrm{R}$ : Let them notice.

$Y$ : Let them notice.

$\mathrm{X} / \mathrm{Y}$ : Yea! 
difference cannot be reduced to mere habitual choice of language, although, clearly, language use is an important aspect of identity and ideology for some people. Two important criteria of division for my informants are being born a Catalan (with or without exposure to the Catalan language and culture) and "feeling" Catalan based on lived experience. Importantly, these criteria are constructed from very different resources. One resource is, or must include, linguistic experience, For some Catalan people, specific linguistic expressions in Spanish (in this case deictics and the transfer of pragmatic usage rules from Catalan to Spanish) may constitute building blocks of an emergent ethnolinguistic identity and ideology. One can interpret the metalinguistic comments as an insight into informants' own perceived ethnolinguistic identities. That is, if people's lives are built from everyday face-to-face interactions in which sociocultural (ethnic) orientation and ideology may be constructed around language use, then there is ethnographic richness in the social meanings that the members of the speech community itself attach to linguistic variation. The particular use of the deictics and their possible role as building blocks of identity and ideology seem to be more salient to those Catalans who have had more experience with (or more exposure to) the Catalan language and culture during their lives. The salience of the specialized use and social role of the deictics is likely to be embedded deeply in the linguistic habitus (Thompson 1991:17) for these people. Such Catalans can use, and recognize the use of, the linguistic resources available to them in their variety of Spanish as another ethnolinguistic and ideological assertion besides language choice, attesting to what Irvine (1989:249) referred to as the "semiotic complexity of language."

ROBERT E. VANN WESTERN MICHIGAN UNIVERSITY

\section{REFERENCES}

Bourdieu, Pierre. Language and Symbolic Power. Edited and Introduced by John B. Thompson. Translated by Gino Raymond \& Matthew Adamson. Cambridge: Harvard UP, 1991.

CUBITT, Tessa. "Network Density among Urban Families." Network Analysis: Studies in Human Interaction. Edited by Jeremy Boissevain and J. Clyde Mitchell. The Hague: Mouton, 1973. 
EAgleton, Terry. "Introduction." Ideology. Edited by Terry Eagleton. New York: Longman, 1994, 1-20.

EDWARDS, Viv. Language in a Black Community. San Diego: CollegeHill, 1986.

FisHMAN, Joshua. "Three Success Stories (more or less): Modern Hebrew, French in Quebec and Catalan in Spain." Reversing Language Shift: Theoretical and Empirical Foundations of Assistance to Threatened Languages. Clevedon: Multilingual Matters, 1991. 287-336.

GAL, Susan. Language Shift: Social Determinants of Linguistic Change in Bilingual Austria. New York: Academic, 1979.

"Language and Political Economy." Annual Review of Anthropology is (1989): 345-367.

GeERTZ, Clifford. "Ideology as a Cultural System." Ideology. Edited by Terry Eagleton. New York: Longman, 1994. 279-294.

IRvINE, Judith. "When Talk Isn't Cheap: Language and Political Economy." American Ethnologist 16 (1989): 248-267.

LaBov, William. Sociolinguistic Patterns. Philadelphia: University of Pennsylvania, 1972.

Milroy, Lesley. Language and Social Networks. 2nd ed. Oxford: Basil Blackwell, 1987 a.

- Observing and Analysing Natural Language. Oxford: Basil Blackwell, $1987 \mathrm{~b}$.

NOYES, Dorothy. "Tradition in Action: The Uses of Folk Culture in Contemporary Catalonia." Catalonia 1992: A European Nation. Barcelona: Llibres de L'índex, 1992. 37-66.

O'Donnell, Paul. "Survey research in Catalonia: Bilingualism and Bias." Catalan Review 3.2 (1989): 125 -136.

SEco, Manuel. "Un Catalanismo Sintáctico en el Español de Hoy." La Corona de Aragón y las Lenguas Románicas. Edited by Günter Holtus, Georges Lüdi and Michael Metzeltin. Tübingen, Germany: Narr, 1989. 309-317.

VANN, Robert E. "Sometimes I Don't Know Whether I'm Coming or Going: Spanish Deictic Systems in Contact with Catalan." Unpublished manuscript presented at LASSO XXII. Arlington, Texas. Oct. 1993.

- Pragmatic and Cultural Aspects of an Emergent Language Variety: The Construction of Catalan Spanish Deictic Expressions (University Microfilms No 9633318). Ann Arbor, MI: Dissertation Abstracts International, 1996.

- "Aspects of Spanish deictic expressions in Barcelona: A Quantitative Examination." Manuscript, Western Michigan University (In preparation). 
WOOLARD, Kathryn. "Language Variation and Cultural Hegemony: toward an Integration of Sociolinguistic and Social Theory." American Ethnologist 12.4 (1985): 738-748.

- Doubletalk: Bilingualism and the Politics of Ethnicity in Catalonia. Stanford, California: Stanford UP, 1989.

APPENDIX: QUESTIONNAIRE FOR IDENTITY AND IDEOLOGY

i) De tus tres mejores amigos, ¿cuántos son catalanes?

2) ¿Cuántos son castellanos?

3) ¿A qué ocupación te quieres dedicar en el futuro?

4) ¿Opinas que Cataluña es una nación, tal como Francia, España, e Italia?

5) ¿Tienes una opinión positiva, negativa, o más bien neutra sobre la monarquía?

6) ¿Eres aficionado al Barça, al Madrid, o a otro club?

7) ¿Te gustaría la independencia total de Catalunaa?

8) ¿Tienes una opinión positiva o negativa de los catalanistas?

9) ¿Tienes una opinión positiva o negativa de España?

I0) ¿Te parece bien el bilinguismo en Barcelona?

II) ¿Dominas una lengua mejor que la otra ahora? ¿Cuál?

12) Con gente bilingüe, ¿qué lengua prefieres hablar?

13) ¿Te pasa que a veces comienzas a decir algo en castellano y terminas en catalán?

14) ¿Te pasa que a veces comienzas a decir algo en catalán y terminas en castellano?

15) ¿Qué lengua hablas la mayoría del tiempo?

16) ¿Te interesan los toros?

17) ¿Te gusta el programa "Personas Humanas?"

I8) ¿Cuál es tu emisora predilecta?

19) En qué canal ves las noticias?

20) ¿Cómo te identificas, como catalán(a) o como español(a) culturalmente? políticamente? ideológicamente? lingüísticamente?

2I) ¿Qué te consideras más que nada, español(a) o catalán(a)?

English version

I) Of your three best friends, how many are Catalans?

2) How many are Castilians? 
3) To what job do you plan to dedicate yourself in the future?

4) Do you feel that Catalonia is a nation, just like France, Spain, and Italy?

5) Do you have a positive, negative, or neutral opinion about the Monarchy?

6) Are you a fan of Barcelona's sport's club, Madrid's sports club, or some other team?

7) Would you like the total independence of Catalonia?

8) Do you have a positive or negative opinion of Catalanists?

9) Do you have a positive or negative opinion of Spain?

10) Do you think bilingualism is a good idea in Barcelona?

II) Do you presently negotiate one language better than the other? Which one?

I2) With bilingual people, what language do you prefer to speak?

13) Do you ever notice yourself starting to say something in Castilian and ending in Catalan?

14) Do you ever notice yourself starting to say something in Catalan and ending in Castilian?

15) Which language do you speak most of the time?

16) Do you like bullfights?

17) Do you like the TV show "Human People?"

18) What is your favorite radio station?

I9) What channel do you watch for news?

20) How do you identify yourself, as a Catalan or as a Spaniard culturally? politically? ideologically?

2I) What do you consider yourself to be more than anything, Spanish or Catalan? 